\title{
Corn Brownies Making Entrepreneurship Training in The Turi Distric
}

\section{Pelatihan Kewirausahaan Pembuatan Brownies Jagung Di Dusun Turi}

\author{
Wasito Wasito*, Dyah Hadi Novida, Ida Fitriani \\ Sekolah Tinggi IImu Ekonomi Muhammadiyah Tuban
}

Community service programs in the form of Entrepreneurship training were carried out in Turi Village, Turirejo Village, Kedamean District, Gesik Regency on August 21, 2017. This activity is the flagship work program of the $2017 \mathrm{KKN}$ management study program. The name of this activity is "Entrepreneurship Training for Making Corn Brownies" with participants PKK mothers and residents of Turi Hamlet. In the training, material with the concept of motivation and entrepreneurship was presented, as well as a cooking demonstration for making corn brownies. The aim of carrying out a work program on entrepreneurship socialization is to provide knowledge to the PKK group of women and Turi hamlet residents about the management and use of local materials such as corn to become entrepreneurial opportunities. Utilization of local potentials owned by the people of Turi hamlet can increase their income with creative capital in managing the agricultural products they have and especially increasing the selling value of corn.

Keywords: Entrepreneurship, Product innovation, Yields, PKK Moms

\section{PENDAHULUAN}

Desa Turirejo memiliki beberapa Dusun yang terbagi menjadi 7 dengan jumlah Rukun Tetangga (RT) yang berbeda-beda yaitu Dusun Turi, Dusun Lempung, Dusun Rayung, Dusun Bunton, Dusun Kembangan, Dusun Sukorejo, dan Dusun Pojok. Dusun Turi, Desa Turirejo

OPEN ACCESS

ISSN 2615-6180 (online)

*Correspondence:

Wasito Wasito

Wasito@gmail.com

Citation:

Wasito W, Novida DH and Fitriani I (2018) Corn Brownies Making Entrepreneurship Training in The Turi

Distric.

Indonesian Journal of Cultural and Community Development. 1:2. Kecamatan Kedamean Kabupaten Gresik merupakan salah satu daerah perseberan terlaksananya kegiatan Kuliah Kerja Nyata (KKN).

Di Indonesia salah satunya adalah di daerah Madura, jagung di gunakan sebagai bahan makanan pokok yang menjadi sumber pangan alternative. Banyak manfaat yang bisa dimanfaatkan dari pengolahan jagung, selain sebagai sumber karbohidrat bagi manusia jagung juga bisa dimanfaatkan sebagai pakan bagi ternak, sehingga di Indonesia sudah banyak kreatifitas dan inovasi yang muncul dalam pemanfaatn dan pengolahan jagung. Kami pun berusaha untuk meningkatkan harga jual dari jagung itu sendiri yang ada di dusun Turi, karena dari hasil survey yang kami lakukan di ibu-ibu PKK yang ada di dusun Turi sebagian besar mereka belum tau bagaimana melakukan inovasi pengolahan jagung selain dimasak sebagai sayur.

Banyaknya hasil panen jagung yang melimpah, namun warga belum bisa memanfaatkan hasil panen jagung dengan inovasi pejualan mereka, biasanya jagung yang telah dipanen hanya di jual langsung ke tengkulak sehingga tidak ada inovasi tentang olahan jagung, dan kurangnya 
pangsa pasar menjadi salah satu factor yang menjadikan mereka hanya berfikir untuk menyerahkan langsung hasil panen ke tengkulak. Disisi lain, masyarakat di lingkungan tersebut hanya beberapa yang memiliki usaha sampingan, sehingga mayoritas masyarakat mendapatkan penghasilan hanya mengandalkan dari hasil panen saja Lynton and Pareek (1984) .

Brownies merupakan salah satu kue khas negeri Paman Sam (Amerika) yang memiliki bentuk yang bantet sehingga bahan baku utama bisa diganti dengan bahan baku yang lainnya Nirmala et al. (????) . Biasanya dipasaran hanya menyediakan brownies original dengan dominasi bahan-bahan coklat. Berkembangnya kreatifitas manusia membuat brownies sekarang memiliki banyak variasi namun perubahan yang dilakukan kebanyakan hanya terletak pada topingnya. Maka dari itu kami memberikan inovasi baru dengan berkreasi menambahkan bahan baku brownies dengan olahan jagung. Brownies di Indonesia memang bervariasi karena kekreatifan orang Indonesia itu sendiri, meskipun bahan baku dari brownies tersebut dirubah namun tidak merubah cir khas dari brownies itu sendiri.

Disini kami melakukan inovasi pembuatan brownies dengan bahan baku utamanya adalah jagung yang juga merupakan tanaman unggulan di Desa Turirejo dan untuk meingkatkan nilai jual jagung yang sebelumnya hanya dijual langsung ke tengkulak. Kami melakukan Pelatihan Kewirausahaan Pembuatan Brownies Jagung dengan target Ibu-ibu PKK khususnya yang berada di lingkungan Dusun Turi sebagai audiensnya. Dengan adanya Pelatihan Kewirausahaan Pembuatan Brownies Jagung, diharapkan Ibu-ibu PKK dan warga Dusun Turi bisa menjadikan pelatihan tersebut sebagai ide untuk berwirausaha dengan menginovasi jagung menjadi produk olahan yang juga memberikan pendapatan baru bagi Ibu-ibu PKK dan warga Dusun Turi, serta memanfaatkan waktu luang selain bertani di sawah.

\section{METODE}

Kegiatan pengabdian diawali dengan melakukan survei ke lapangan untuk menentukan tempat pelatihan dan penentuan kelompok di Dusun Turi. Selanjutnya dilaksanakan secara bertahap kegiatan meliputi sosialisasi kegiatan, penyediaan bahan dan peralatan, cara atau teknik Kewirausahaan, monitoring kegiatan, dan evaluasi kegiatan. Pelaksanaan pengabdian dilakukan kepada anggota kelompok Ibu-ibu PKK khususnya yang berada dilingkungan Dusun Turi, Desa Turirejo, Kecamatan Kedamean, Kabupaten Gresik. Perintisan kerjasama antara anggota kelompok Ibu-ibu PKK dengan stakeholder lainnya. Dalam kegiatan sosialisasi mengenai teknik berwirausaha.

Kami melakukan pendekatan kepada Ibu-ibu PKK dan warga Dusun Turi untuk mencari informasi mengenai pemanfaatan dan pengolahan hasil panen yang ada di Desa Turirejo. Persoalan yang dihadapi oleh Ibu-ibu PKK dan warga Dusun Turi adalah kurangnya pengetahuan dalam berinovasi pada pengolahan bahan baku jagung yang juga merupakan tanaman unggulan di Desa Turirejo. Masyarakat lebih memilih untuk menjual langsung hasil panen jagung pada tengkulak \&amp; Agato and Narsih (2011) .

Saat ini menjadi pengusaha atau membuka usaha secara mandiri sangat diminati oleh masyarakat Indonesia. Hal ini menjadi penting karena berwirausaha memiliki keuntungan yang cukup besar dibandingkan dengan menjadi pegawai maupun buruh. Wirausaha juga memungkinkan untuk sesesorang membuka lapangan pekerjaan baru bagi mereka yang sedang membutuhkan pekerjaan. Banyak hal yang musti dipersiapkan sebelum kita memulai usaha yang akan di rintis agar semua sesuai dengan apa yang diinginkan. Planning menjadi pondasi awal ketika memulai merintis sebuah usaha agar usaha tersebut dapat berjalan dengan lancar Iskandar and Kewirausahaan (????) .

Salah satu sasaran yang harus diasah kemandiriannya untuk memulai kegiatan berwirausaha adalah ibu-ibu PKK. Hasil survey yang kami lakukan sebelum melakukan pelatihan adalah sebagian besar ibu-ibu yang ada di dusun Turi hanya membantu suami bekerja mengolah ladang sawah yang mereka miliki dan sebagian lain hanya menjadi ibu rumah tangga. Oleh karena itu, kami memilih ibu-ibu PKK sebagai peserta pelatihan yang kami adakan, sehingga kami berharap bahwa ibu-ibu PKK dapat meningkatkan taraf kehidupan mereka bisa lebih baik. 
Setelah data diperoleh dari Ibu-ibu PKK dan warga Dusun Turi kemudian dilakukan kegiatan mengenai pemahaman tentang berwirausaha dengan produk dari jagung yang bisa di inovasi menjadi produk olahan makanan seperti Brownies Kusus Jagung. Dengan adanya kegiatan tersebut, dapat meningkatkan nilai jual dari jagung yang sebelumnya hanya dijual langsung dalam bentuk bahan mentah.

Teknik Pengambilan Data

Teknik pengambilan data dilakukan dengan survei dan wawancara kepada Ibu-ibu PKK dan warga Dusun Turi, hal ini dilakukan untuk mencari informasi mengenai pemanfaatan dan pengolahan hasil panen di Desa Turirejo khususnya Dusun Turi.

\section{Model Pembinaan}

1. Memberikan pemahaman pada Ibu-ibu PKK dan warga Dusun Turi untuk melakukan Kewirausahaan yang baik dan tepat sasaran.

2. Melakukan pembinaan dengan cara penyuluhan, pelatihan dan demontrasi Kewirausahaan brownies jagung.

3. Melakukan pendampingan kepada Ibu

4. Melakukan monitoring dan evaluasi terhadap kegiatan yang telah dilakukan Ibu

5. Mempertahankan/meningkatkan kualitas dari produk Ibu-ibu PKK dan warga Dusun turi yakni brownies jagung.

6. Meningkatkan semangat berwirausaha kepada anggota Ibu

\section{Tahapan Kegiatan}

1. Sosialisasi rencana kegiatan, memberitahukan kepada kelompok sasaran yakni Ibu-ibu PKK dan warga Dusun Turi untuk mengikuti acara pelatihan kewirausahaan pada tanggal 21 Agustus 2017 pada jam 18.30 WIB (habis sholat Maghrib),

2. Persiapan teknis Kewirausahaan, Persiapan teknis untuk pelatihan Ibu-ibu PKK dan warga Dusun Turi melalui kegiatan pengabdian,

3. Pengadaan peralatan untuk pelatihan pembuatan brownies jagung seperti; bahan membuat roti, jagung, mixer, alat pengukus, dll

4. Melakukan penyuluhan, pelatihan, demontrasi dan pendampingan pada anggota Ibu

5. Pelatihan Kewirausahaan brownies jagung

Kegiatan KKN yang dilakukan di Dusun Turi Desa Turirejo, Kecamatan Kedamean, Kabupaten Gresik, bermaksud untuk memberikan pengabdian kepada masyarakat Dusun Turi. Dari informasi yang diperoleh, banyak warga yang kurang pengetahuan dalam mengelola hasil panen. Pengelolahan yang akan digunakan dalam pelatihan kepada Ibu-ibu PKK dan warga Dusun Turi dalam kegiatan Pelatihan Kewirausahaan melalui pemanfaatan sumber daya lokal seperti jagung, kangkung, dan kacang panjang yang selama ini belum dimanfaatkan dan dikelola secara optimal.

Kegiatan ini dilakukan dengan penekanan pada metode partisipasi aktif kelompok sasaran. Kelompok sasaran yang terlibat dalam kegiatan ini adalah kelompok ibu-ibu yang tergabung dalam Pembinaan Kesejahteraan Keluarga "PKK" dan warga Dusun Turi. Pendekatan pada metode ini diharapkan kelompok Ibu-ibu PKK dan warga Dusun Turi dapat menguasai Kewirausahaan. Mekanisme kegiatan ini akan dilaksanakan melalui beberapa tahap yaitu: penetapan kelompok sasaran, sosialisasi, kegiatan lapangan, dan pembinaan Suratmi et al. (2012) .

Kegiatan sosialisasi dilaksanakan dengan tujuan untuk memberi pengetahuan kepada kelompok Ibu-ibu PKK dan warga Dusun Turi tentang pengelolahan dan pemanfaatan bahan lokal menjadi peluang berwirausaha. Pada acara kegiatan sosialisasi, diperkenalkan alat dan bahan, teknik pengelolahan dan pemanfaatan bahan lokal, serta manfaatnya bagi anggota kelompok Ibu-ibu PKK dan warga Dusun Turi.

Materi yang disajikan merupakan konsep motivasi dan konsep kewirausahaan Benediktus and Joko (2013) . Dalam materi motivasi, warga diberikan contoh-contoh orang-orang yang sudah sukses melakukan wirausaha. Dalam konsep kewirausahaan ibu-ibu PKK dan warga diberikan materi dasar mengenai bagaiamana planning awal membuka usaha sehingga usaha tersebut dapat berjalan lancar dan sesuai dengan target yang di inginkan Midori et al. (2012) . 


\section{HASIL DAN PEMBAHASAN}

Hasil dari kegiatan pengabdian ini dapat dilihat pada peningkatan animo anggota kelompok Ibu-ibu PKK dan warga Dusun turi untuk bersama-sama mengembangkan pengolahan bahan lokal seperti jagung menjadi Brownies Kukus Jagung sehingga dapat membantu meningkatan pendapatan keluarga Ibu-ibu PKK dan warga Dusun Turi.

Dengan adanya kegiatan sosialisasi telah menambah wawasan dan partisipasi anggota Ibuibu PKK dan warga Dusun Turi untuk memanfaatkan sumberdaya lokal sehingga dapat mendukung upaya peningkatan kesejahteraan ekonomi keluarga Ibu-ibu PKK dan warga Dusun Turi.

Evaluasi disusun untuk mengetahui pencapaian dari setiap tahapan kegiatan yang dilaksanakan. Berdasarkan evaluasi ini dapat diketahui faktor-faktor yang menentukan keberhasilan kegiatan pengabdian. Susunan evaluasi terdiri atas penilaian motivasi khalayak sasaran, kemampuan dan keterampilan anggota kelompok dan keberlangsungan kegiatan. Evaluasi dilakukan pada kegiatan sosialisasi dan kegiatan lapangan

\section{KESIMPULAN}

Dari hasil kegiatan pengabdian berupa pelatihan dan demontrasi Kewirausahaan Brownies Jagung secara langsung kepada anggota kelompok Ibu-ibu PKK dan warga Dusun Turi, Desa Turirejo, Kecamatan Kedamean, Kabupaten Gresik, mengenai Kewirausahaan yang telah menambah wawasan dan animo anggota Ibu-ibu PKK dan warga Dusun Turi untuk berusaha meningkatkan semangat berwirausaha, sehingga anggota Ibu-ibu PKK dan warga Dusun Turi bisa menambah pendapatan baru dari berwirausaha.

Mengingat sarana dan prasarana yang ada saat ini masih terbatas dan pada musim-musim tertentu jagung dapat di panen maka perlu suatu upaya untuk melakukan inovasi terhadap hasil panen lainnya sehingga tidak mengganggu proses berwirausaha dan kepada pemerintahan setempat dibentuk UMKM yang dikelola Ibu-ibu PKK dan warga Dusun Turi untuk memudahkan warga dalam berwirausaha dan berintegrasi dengan kelompok tani setempat untuk supply jagung.

\section{REFERENCES}

\&amp; Agato and Narsih (2011)

Benediktus, S. and Joko (2013). Magister Agribisnis Program Pascasarjana UNS 1, 33-44.

Iskandar, S. T. and Kewirausahaan, M. U. (????). www. iskandarst.com/motivasi-untuk-berwirausaha.

Lynton, P. and Pareek, U. (1984).

Midori, Y., Danang, Izzaty, R., and Maria (2012). Peningkatan Keterampilan Wirausaha Kelompok Tani Dewi Ratih Iii Desa Sukoanyar-Pakis, Kabupaten Malang Melalui Diversifikasi Produk Olahan Ubi Jalar. Fakultas Teknologi Pertanian Universitas Brawijaya (Malang).

Nirmala, M., Tawali, A. B., Zainal, M., and Mahendaratta (????)

Suratmi, N., Ika, C., and Indawati (2012). Menumbuh Kembangkan Jiwa Kewirausahaan Masyarakat Miskin Pegu nungan Kapur Malang Selatan dengan 'tiwul' Sebagai Produk Komersial Unggulan Melalui Kuliah Kerja nyata Pem- belajaran Peran Masyarakat (KKN-PPM). Fakultas Keguruan dan Ilmu Pendidikan (Malang).

Conflict of Interest Statement: The authors declare that the research was conducted in the absence of any commercial or financial relationships that could be construed as a potential conflict of interest.

Copyright (c) 2018 Wasito, Novida and Fitriani. This is an openaccess article distributed under the terms of the Creative Commons Attribution License (CC BY). The use, distribution or reproduction in other forums is permitted, provided the original author(s) and the copyright owner(s) are credited and that the original publication in this journal is cited, in accordance with accepted academic practice. No use, distribution or reproduction is permitted which does not comply with these terms. 